\title{
A STUDY OF EMBANKMENT PERFORMANCE DURING OVERTOPPING
}

\author{
by
}

Paul A. Gilbert, S. Paul Miller

Geotechnical Laboratory

DEPARTMENT OF THE ARMY

Waterways Experiment Station, Corps of Engineers 3909 Halls Ferry Road, Vicksburg, Mississippi $39180-6199$

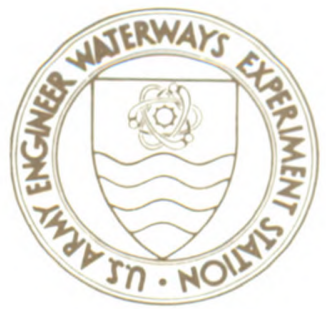

November 1991

Final Report

Approved For Public Release; Distribution Is Unlimited

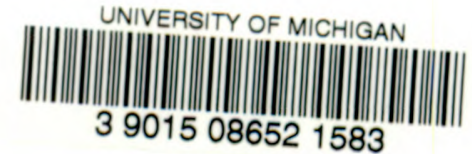

Prepared for DEPARTMENT OF THE ARMY

US Army Corps of Engineers

Washington, DC 20314-1000

Under CWIS Work Unit 81710 